\title{
Lægelig, psykologisk og pædagogisk behandling af lovovertrædere i Island.
}

Af højesteretssagf $\varnothing$ rer SVEINBJÖRN JÓNSSON og overlæge, dr, med. HELGI TOMASSON.

På det ovenanf $\emptyset$ rte område gælder $\mathrm{i}$ henhold til islandsk lov $\mathrm{i}$ hovedtrækkene følgende regler.

\section{Pædagogisk behandling.}

I henhold til art. 14 i almindelig straffelov nr, 191940 er den kriminelle lovsalder 15 år. Yngre personer er efter som forholdene kræver på den sædvanlige måde underkastet forældres, læreres, børneværns og skolekommissioners opsyn.

Ved den almindelige straffelovs art. 30 bemyndiges justitsministeren, efter at have indhentet b $\phi$ rneværnets (skolekommissionens) sk $\phi \mathrm{n}$ til at bestemme, ,, at sagsanlæg $i$ anledning af forseelser, der er begået af unge mennesker $\mathrm{i}$ alderen $15-18$ år, kan bortfalde på betingelse af, at det unge menneske $i$ et bestemt tidsrum, dog ikke længer end til det fyldte 21 år, stilles under et passende opsyn såsom af en institution eller privatperson, der vil påtage sig dette." Dersom det unge menneske $\mathrm{i}$ opsynstiden g $\phi \mathrm{r}$ sig skyldig $\mathrm{i}$ en ny forseelse eller betydelig ulydighed mod den person, der ud $\phi$ ver opsynet, kan sagen optages påny, ligeledes efter at børneværnets eller skolekommissionens sk $\phi \mathrm{n}$ er blevet indhentet.

Når hjemmelen $\mathrm{i}$ den almindelige straffelovs art. 56 til at afsige en betinget straffedom bringes til anvendelse, kan straffens udsættelse i henhold til nævnte artikel ,g $\phi$ res afhængig af at den d $\varnothing$ mte, sålænge prøvetiden varer, står under opsyn af en institution eller privatperson, der må anses for egnet dertil og er villig til at påtage sig opsynet."

Som allerede anf $\varnothing \mathrm{rt}$ og straffelovens art. 30 udviser, er det en ved lov fastsat betingelse for at ministeren kan lade sagsanlæg bortfalde i anledning af unge menneskers lovovertrædelser i 15-18 års alderen, at det unge menneske står under et passende opsyn $\mathrm{i}$ et bestemt tidsrum, dog ikke længere end til det fyldte 21. år. Denne betingelse synes altid at være blevet overholdt. Efter at børneværnene blev oprettet ved lov nr. 43, 1932, synes det stadig at være blevet stillet som betingelse for sagsanlægs bortfald mod unge mennesker, at de stilledes under disses opsyn. I art. 1, 5. stykke i lov nr. 29, 1947, om børns og unge menneskers beskyttelse, jfr. samme lovs art. 2 og 5 , består en del af børneværnenes og børneværnsrådets opgave i opsyn med unge mennesker, der har forset sig mod loven. 
I henhold til lovens art. 4, skal der være børneværn i hver af landets $\mathrm{k} \phi$ bstæder. Udenfor k $\phi$ bstæderne ud $\varnothing \mathrm{ver}$ skolekommissionerne b $\phi$ rneværnenes hverv.

I lovens art. 31 jfr. samme lovs art. 28 hedder det, at dersom et børneværn bliver opmærksomt på, at et ungt menneskes opf $\varnothing$ rsel lader tilbage at $\emptyset$ nske, såsom på grund af .... lovovertrædelser, skal børneværnet „søge at forbedre dets optræden og opf $ø$ rsel ved anvisninger og formaninger, samtaler med de pårørende, herskaber, lærere, mestre o. s. v." Hvis et ungt menneske bedrer sig efter børneværnets formaninger og underkaster sig dets foranstaltninger, såsom anbringelse i kondition eller lære, er børneværnene forpligtet til at yde deres støtte hertil, „forsåvidt som en dommer eller minister ikke træffer andre foranstaltninger med hensyn til et ungt menneske, der har overtrådt loven og er ældre end 15 år". Endvidere er vedkommende børneværn forpligtet til at yde et ungt menneske, der efter afsluttet tjenestetid har forladt en plads, hvor det er blevet anbragt på børneværnets foranledning, st $\varnothing$ tte ved anskaffelse af arbejde eller læreplads, der svarer til dets evner.

F $\varnothing \mathbf{r}$ et barn eller ungt menneske, der er legemlig eller moralsk underlødigt, bl. a. unge lovovertrædere, anbringes i henhold til loven, ,skal børneværnet eller børneværnsrådet, hvis det lader sig gøre, lade en specialist unders $\emptyset$ ge barnet eller det unge menneske og anvise, hvorledes det $b \phi \mathbf{r}$ behandles." Regeringen skal ,eftersom der bevilliges tilskud dertil på finansloven" efter at have indhentet børneværnsrådets forslag, oprette og drive et institut i dette øjemed. Alle børneværn rundt omkring i landet ville have lejlighed til forel $\phi$ big at anbringe unge mennesker, der har overtrådt loven, i et sådant institut, jfr. art. 36. Et sådant institut er dog endnu ikke blevet oprettet, som der nærmere vil blive kommet ind på.

Endvidere skal regeringen if $\oint$ lge art. 37 „eftersom der bevilliges midler dertil på finansloven" oprette og drive et asyl for børn og unge mennesker, der har begået lovovertrædelser eller på anden måde er kommet på et skråplan. Der gås ud fra at der bliver to asyler, det ene for piger men det andet for drenge. Hvorledes end kommissioner anbringer børn og unge mennesker, er de dog tilligemed børneværnsrådet forpligtet til at føre opsyn med deres befindende og hele deres pleje. Det i art. 36 i lov om børn og unge menneskers beskyttelse omhandlede unders $\varnothing$ gelsesinstitut er endnu ikke blevet oprettet, men Reykjaviks børneværn og børneværnsrådet har igennem mange år haft en udmærket specialist, en doktor i psykologi og nuværende professor i dette fag ved Islands Universitet i sin tjeneste. Endvidere har børneværnet til stadighed haft en sygeplejerske og læge efter behov i sin tjeneste. En læge og en sygeplejerske er også altid medlemmer af Reykjaviks børneværn. Det er således altid det f $\emptyset$ rste der sker, når børneværnene får med et ungt menneske at gøre, at lade en specialist undersфge dets hele tilstand så vidt som forholdene tillader og omstændighederne menes at kræve. Selvom unders $\phi$ gelsesinstitutet endnu ikke er 
blevet oprettet, er der dog gennem flere år blevet drevet et optagelseshjem for hele landet. Det oprettedes af staten i 1945. Det er beregnet til at være og er blevet anvendt som opholdssted for vanskelige b $\varnothing \mathrm{rn}$ og unge mennesker, medens der træffes bestemmelser om deres fremtidige behandling. Dette optagelseshjem ligger i Ellidahvammur i Reykjaviks omegn. I dette optagelseshjem var der i 194353 børn og unge mennesker, i 1946 53, i 1947 62, i 1948 49, i 194972 og 195054.

Selvf $\phi$ lgelig kommer de allerfleste af b $\phi$ rnene og de unge mennesker fra Reykjavik, idet denne bys indbyggerantal udg $\phi \mathrm{r}$ en forholdsvis stor del af landets befolkning. De asyler, der omhandles i lovens art. $37 \mathrm{og}$ som er blevet nævnt her foran, er heller ikke blevet oprettet endnu. Derimod er der her og der blevet oprettet nogle mindre b $\phi$ rnehjem, dels beregnet til sommerferieophold, dels til længere ophold. $P a ̊$ grund af folkets fåtallighed, ca. $140.000 \mathrm{og}$ af at antallet af de personer, som det har været n $\phi$ dvendigt at anbringe, derfor har været ringe, har det trukket ud med oprettelsen af disse asyler, og man har ladet sig nøje med at der træffes andre foranstaltninger, der forel $\phi$ big er blevet anset for tilstrækkelige.

Den hovedfremtidsforanstaltning børneværnene har truffet med hensyn til unge mennesker, der har forset sig mod loven, har bestået $i$ anbringelse $i$ hjem på landet og for en del i hjem i byerne, særlig når det har drejet sig om unge børn. Island er et vidtstrakt land $\mathbf{i}$ forhold til indbyggerantallet, og bebyggelsen derfor stærkt spredt. Der er et stort antal gode, mere eller mindre afsidesliggende hjem $i$ landet. I sådanne hjem har børneværnene anset det for hensigtsmæssigt at anbringe unge mennesker på arbejde eller til anden opdragelse for længere tidsrum. Arbejdet og omgangen med naturen har i mange tilfælde bragt heldige resultater, selvom det på den anden side ret ofte har vist sig, at unge mennesker har været ustadige i deres plads, og at husb $\phi$ nderne er blevet trætte af at have dem. Som et eksempel på Reykjaviks børneværns erfaring med hensyn til arbejdets opdragende magt, kan der henvises til et stykke af dets årsberetning for året 1941, hvor der udtales: „Børns og unge menneskers lovovertrædelser har i årets $1 \varnothing \mathrm{b}$ været i stærk tilbagegang. Iår blev 108 børn, 16 år gamle og yngre, (deraf 12 piger) fundet skyldige i i det hele 169 overtrædelser, medens ifjor 212 børn i samme alder fandtes skyldige i 341 overtrædelser. I ingen af årene medregnes overtrædelser af byens politivedtægt .... Tyverier blandt drenge indtil 16 års alder var betænkelig mange i årene 1937 —40. De var i tiltagende i årene 1937-39, men har været i stærk tilbagegang $i$ årene $1940 \mathrm{og} 1941 \mathrm{og}$ det samme kan siges om de fleste af b $\wp \mathbf{r n s}$ forseelser. Hovedgrunden til at skarnsstreger hos b $\phi \mathrm{rn}$ har været i tilbagegang, må uden tvivl søges i de for $\emptyset$ gede arbejdsmuligheder".

Hvorvidt denne slutning kan holde stik får stå hen. Antallet af børn og unge mennesker indtil 16 år, der har forset sig, samt af deres forseelser har if $\varnothing$ lge børneværnets beretninger $\mathrm{i}$ årene $1938-50$, været som følger: 


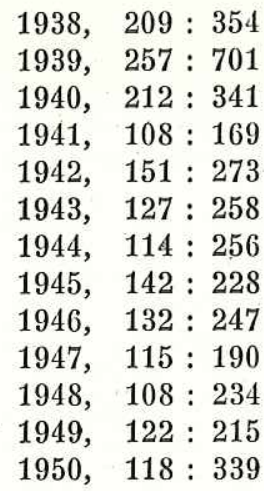

Her er alle vedkommende forseelser, små og store, medregnet.

I disse år er byens indbyggerantal steget fra 37.366 til 57.563.

Det må anses for fuldtud givet, at hjemmene på landet med deres arbejde og ro er vore bedste opdragelsesanstalter, selvom det naturligvis har store hager ved sig at anbringe unge lovovertrædere $\mathbf{i}$ afsidesliggende hjem på landet, ikke mindst med hensyn til hjemmene.

Blandt andet kan en fordel ved at anbringe unge mennesker i hjem på landet anføres. En af de ting der på grund af det lave indbyggerantal kan forvolde vanskeligheder her $\mathrm{i}$ landet, hvor så at sige alle kender hverandre, er, hvorledes de unge mennesker skal skjules for omverdenen. Af begribelige grunde kan det være en hjælp ved et ungt menneskes — som forøvrigt også voksnes — omvendelse, at det ikke kommer alt for meget $\mathrm{i}$ rampelyset. Desuden er hele tonen i et sådant hjem en anden, end i omgangen med lignende unge mennesker på byens gader eller i hjemmene for vanskelige børn.

Sagsanlægs bortfald $\mathrm{i}$ henhold til den almindelige straffelovs art. 30 har if $\varnothing$ lge børneværnets beretning i Reykjavik fordelt sig på de sidstforl $\varnothing$ bne 5 år på f $\varnothing$ lgende måde: 1946 5, 1947 2, 1948 13, 194938 og 195024.

Hvad angår betingede straffedomme $\mathrm{i}$ henhold til den almindelige straffelovs art. 56, kan man med sikkerhed hævde, at domstolene i almindelighed ikke har stillet det som betingelse for en sådan strafs opsættelse, at den d $\varnothing$ mte, sålænge pr $\varnothing$ vetiden varede, stilledes under et instituts eller en privatpersons opsigt.

Hvis man ville slå ind på den bane, ville det uden tvivl blive børneværnene eller børneværnsrådet, som sådanne unge mennesker, eftersom det ansås for hensigtsmæssigt, blev henvist til. Til forklaring kan der peges på, at i de sidstforl $\phi$ bne 5 år er tallet af betinget d $\varnothing \mathrm{mte}$ i Reykjavik som følger: 1946, 57, 1947 5, 1948 49, 194953 og 195050.

I den almindelige straffelovs art. 43 bestemmes der, at der kan oprettes et fængsel eller en fængselsafdeling for fanger, der er blevet dømt inden deres fyldte 22 . år, med en særlig behandling med hensyn til deres opdragelse. 
Der bør da lægges særlig vægt på at fremme fangernes åndelige og legemlige udvikling ved undervisning, legems $\varnothing$ velser og velegnet udendørsarbejde, som også ved at give dem undervisning i sådanne fag, der senere kan blive dem til nytte, når de har generhvervet deres frihed. Et sådant fængsel eller fængselsafdeling er endnu ikke blevet oprettet, og grunden hertil vil hovedsagelig være den samme, der er anført her foran i forbindelse med bygningen af ungdomshjem, nemlig befolkningens fåtallighed. Planen er dog at oprette sådanne anstalter hurtigst muligt.

Her foran har vi i store træk gjort rede for den islandske rets hovedregler angående lovovertræderes pædagogiske behandling.

\section{Lægelig behandling.}

I henhold til den almindelige straffelovs art. 15 ,skal de personer ikke straffes, der på grund af sindssyge, manglende åndelig udvikling, affældighed, bevidsthedstab eller anden tilsvarende tilstand, var på det tidspunkt de udførte gerningen fuldstændig ude af stand til at være herrer over deres gerninger.“ I samme lovs art. 16 hedder det: „Dersom den person, der udførte gerningen, havde nedsatte åndsevner, således f. eks. på grund af manglende udvikling, affældighed, skæv kønslig udvikling eller andre forstyrrelser, men denne hans tilstand dog ikke er tilstede i så høj grad som art. 15 forudsætter, kan vedkommende straffes for forseelsen, hvis der efter omstændighederne og efter at en læges sk $\phi n$ er blevet indhentet, kan gås ud fra at straf vil kunne frugte."

I henhold til disse lovparagrafer er det forhørsdommerens opgave at skabe sig en opfattelse af, om det forholder sig således om den person, der har forseet sig, og da, hvis dommeren synes så, at indhente et lægeligt sk $\varnothing$. Helt op til de sidste år er det kun blevet $\mathrm{i}$ ringe grad praktiseret, at forbrydere blev sendt til observation hos en sindssygelæge.

Foruden bestemmelser om sikkerhedsforvaring af personer, der er blevet frikendt $i$ henhold til den almindelige straffelovs art. 15 eller 16 , indeholder lovens art. 62 bestemmelser om at vedkommende kan anbringes i en formålstjenlig anstalt. Der forudsættes selvf $\phi$ lgelig, at der i sådanne anstalter, dersom de bliver oprettet, foretages helbredelsesfors $\varnothing \mathrm{g}$ på de nævnte personer, foruden at de holdes i sikkerhedsforvaring. I sådanne anstalter kan endvidere i henhold til lovens art. 63 2. stykke hensættes personer, der i længere tid har været $\mathrm{i}$ en sådan tilstand som omhandles $i$ art. 15 og 16, efter at de har gjort sig skyldig $\mathrm{i}$ en strafbar handling, men $\mathrm{f} \phi \mathrm{r}$ endelig dom er blevet afsagt $\mathrm{i}$ deres sag. Det asyl, der omhandles i art. 16 2. stykke og i art. 62 er endnu ikke blevet oprettet, men arbejdsanstalten Litla-Hraun og sindssygeanstalten i Kleppur er blevet anvendt eftersom forholdene krævede.

Hvad angår farlige psykopater, er det lidet tilfredsstillende, at der ikke haves en særlig anstalt for dem, men de er så få, at det er fuldstændig udelukket, at det $\mathrm{i}$ en nær fremtid anses for gennemf $\varnothing$ rligt at 
bygge en særlig anstalt for dem. Det ville være i høj grad hensigtsmæssigt for Island, dersom det kunne nå frem til en overenskomst med en af nabostaterne om optagelse af nogle af dets psykopater i deres anstalter.

Til nærmere forklaring skal det oplyses, at der i de sidste 5 år i Island er blevet dømt 4 farlige psykopater.

I den almindelige straffelovs art. 17 udtales der, at $\mathrm{i}$ almindelighed skal straf bringes til anvendelse, selvom forseelsen er begået i beruselse, med mindre der har været tale om fuldkommen bevidstl $\phi$ shed, men da skal der ikke straffes medmindre anklagede forud har vidst eller har haft grund til at tro, at han ville begå forbrydelsen sålænge rusen varede, eller at den ville følge af hans tilstand.

I henhold til art. 64 kan det $\mathrm{i}$ dommen pålægges en person, der er blevet id $\varnothing \mathrm{mt}$ fængselsstraf for en lovovertrædelse, som vedkommende har begået under påvirkning af spiritus, at han hverken køber eller nyder spiritus $i$ et bestemt tidsrum, der dog ikke må overstige 5 år fra afslutning af hans afsoning af straffen, under trusel om arrest eller fængselsstraf i henhold til art. 123 2. stykke. Samme bestemmelse kan indf $\varnothing$ res $i$ dom over en person, der er blevet frikendt $i$ henhold til bestemmelserne $\mathrm{i}$ art. 17, dersom hans gerning $\mathrm{i}$ modsat fald ville være blevet straffet med frihedsstraf.

Sådanne bestemmelser kan træffes i dom over en person, der to gange eller oftere har gjort sig skyldig i lovovertrædelser på grund af beruselse i løbet af de sidste to år, selvom det kun har drejet sig om mindre forseelser.

Det kan være en sk $\phi$ nssag om bestemmelsen i art. 64 bør hellere henregnes til lægelig behandling end til pædagogisk behandling, men vi har anset det for rettest at anføre den her.

Det udtales endvidere i art. 65, at ,dersom det efter sagens omstændigheder synes klart, efter at lægeligt sk $\varnothing n$ er blevet indhentet, at anklagede i henhold til art. 64 1. punktum eller art. 123 1. og 2. punktum ikke er i stand til at beherske sin drankertilb $\varnothing$ jelighed, kan det ved dom bestemmes, at han efter udstået straf eller umiddelbart skal indlægges til behandling $\mathrm{i}$ en dertil egnet anstalt, hvis straffen er betinget. Dommen skal da lyde på et ophold i anstalten på indtil 18 måneder, eller dersom gentagelse finder sted indtil 3 år." Justitsministeren er i henhold til forslag fra anstaltens ledelse eller dens læge, bemyndiget til at bestemme, at der $\mathrm{i}$ et bestemt tilfælde finder en afkortning sted af opholdet $\mathrm{i}$ anstalten, fordi der kan gås ud fra, at den syge er helbredet.

Endelig er der i henhold til art. 39 hjemmel til at overføre fanger, der er svækket på grund af overdreven nydelse af spirituosa eller andre narkotiske midler, til en anstalt; enten foreløbig eller så længe straffetiden varer, „hvis det efter fængselsdirektionens eller fængselslægens sk $\varnothing$ n findes bedre egnet eller udsigtsrigere til at hidføre resultater."

En sådan anstalt for drankere, som der gås ud fra i art. 65 og 39, er 
endnu ikke blevet oprettet, men sagen er i forberedelsesstadiet, og der kan gås ud fra, at der hurtigt vil blive bødet på mangelen af en sådan anstalt. Når der har været tale om sådanne anklagede, hvad dog meget sjældent har været tilfældet, er de blevet indlagt i et sindssygehospital eller et almindeligt sygehus.

I denne forbindelse kan endelig den almindelige straffelovs art. 46 1. stykke nævnes, der udtaler, at dersom en fange indlægges i et sygehus, anses det som om han afsoner sin straf, sålænge han opholder sig der, „medmindre han selv har pådraget sig sygdommen på utilbørlig måde, efter at han begyndte straffens afsoning."

\section{Psykologisk behandling.}

Angående dette punkt er der lidet at bemærke. Islandsk lov indeholder ingen bestemmelse om en special psykologisk behandling af lovovertrædere, udover hvad der selvf $\phi$ lgelig indeholdes i de almindelige lovbestemmelser om straf som helhed, samt lovbestemmelser om lovovertræderes $\varnothing$ vrige behandling, der iblandt deres pædagogiske og lægelige behandling.

Vi forstår den såkaldte „straf“ således, at formålet er, at den pædagogiske, psykologiske og lægelige behandling af lovovertrædere alle er vigtige led i den, særlig den pædagogiske og psykologiske. Dersom det ikke var tilfældet, forekommer det os, at dens berettigelse i almindelighed blev problematisk forsåvidt individet angår.

Sveinbjörn Jónsson. Helgi Tómasson. 